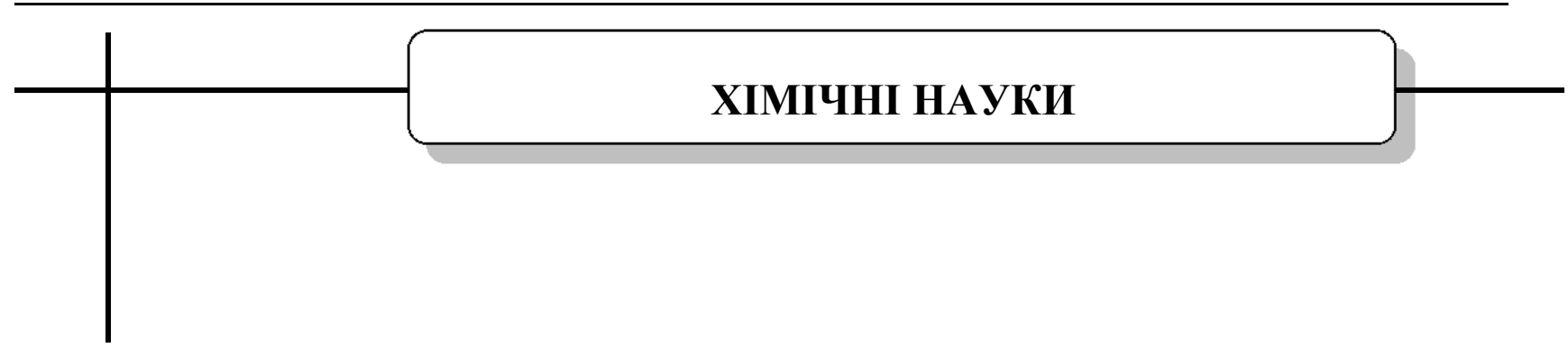

УДК 66.03

DOI: 10.15587/2313-8416.2019.180982

\title{
ДОСЛІДЖЕННЯ АДСОРБЦЙНИХ ВЛАСТИВОСТЕЙ ЧИСТИХ І КОМПОЗИТНИХ ФЕРИТІВ
}

\author{
Н. В. Куцан, В. С. Возняк, І. М. Іваненко
}

У статті представлені результати експериментального дослідження адсорбиійних властивостей нових сорбиійних матеріалів - чистих і композитних нікелевих феритів, по відношенню до барвників аніонної та катіонної природи. Зразки чистих феритів та їх композитів з активним вугіллям були синтезовані методом співосадження. Вивчалась кінетика адсорбційного процесу, розраховувались значення питомої та граничної адсорбиії за різних вихідних концентрацій та тривалості процесу

Ключові слова: адсорбиійні властивості, ферити, синтез сорбентів, кінетика адсобриійного процесу, адсорбиійна ємність

Copyright (C) 2019, N. Kutsan, V. Woznyak, I. Ivanenko. This is an open access article under the CC BY license (http://creativecommons.org/licenses/by/4.0).

\section{1. Вступ}

Велика кількість неорганічних і органічних відходів, що утворюються в результаті життєдіяльності людини, приводить до значних забруднень водойм, які згубно впливають на здоров'я усіх живих організмів. Забруднення води в даний час є однією з найбільш серйозних екологічних проблем, які перешкоджають розвитку суспільства. Зокрема, кольорові забруднення викликають стурбованість у науковців через токсичний вплив забарвлюючих речовин. Наявність органічних барвників у стічних водах зумовлена їх широким застосуванням в таких галузях, як текстильна, паперова, поліграфічна, фармацевтична промисловість, шкіряна, косметична, пластикова та інші напрямки діяльності, які є основними джерелами промислових стічних вод. Кількість стічних вод, забруднених барвниками, надзвичайно велика. Як правило, об'єм, що потрапляє у стічні води з кожної стадії текстильної операції складає приблизно 50 дм $^{3} /$ кг продукту [1]. Крім того, барвники не піддаються біологічному розкладанню, вони залишаються стабільними в різних умовах завдяки синтетичному походженню i складній ароматичній структурі. У зв'язку із цим пошук та розробка нових, більш ефективних методів видалення барвників зі стічних вод перед їх скиданням $€$ актуальною практичною задачею.

\section{2. Літературний огляд}

Наразі існує багато методів очищення стічних вод від барвників, включаючи:
- фотокаталітичну деградацію [2];

- коагуляцію [3];

- електрохімічні процеси [4];

- хімічне окиснення [5];

- мембранну фільтрацію [6];

- біологічне очищення [7];

- адсорбцію [8].

Серед перерахованих методів очищення стічних вод від барвників широко використовується адсорбція завдяки своїй простоті, високій ефективності та економічності. У якості адсорбентів застосовують різні матеріали, які на належному рівні знебарвлюють стічні води, а саме: активоване вугілля, каолін, глина, відпрацьовані іоніти, тощо.

Так, наприклад, авторами роботи [9] отримано порошки феритів загальної формули $\mathrm{NiCr}_{\mathrm{x}} \mathrm{Fe}_{2-\mathrm{x}} \mathrm{O}_{4}$ та проведено дослідження їх сорбційних характеристик, експериментально встановлено величини питомої площі поверхні. Автори роботи [10] проводили дослідження адсорбційної активності феритів по відношенню до барвника конго червоного, в залежності від тривалості взаємодії та від початкової концентрації барвника.

У зв'язку із цим, вивчення адсорбційних властивостей нового класу сорбційних матеріалів - нікелевих феритів та їх композитів, є актуальною задачею, що зумовлена наявністю їх високої адсорбційної ємності та значної намагніченості водночас. Це робить ферити перспективним адсорбційним магнітовідділяємим матеріалом. 


\section{3. Мета і задачі дослідження}

Мета дослідження - синтезувати чисті ферити та їх композити з активним вугіллям та дослідити їх адсорбційні властивості по відношенню до барвників аніонного та катіонного типів.

Для досягнення поставленої мети вирішувались наступні задачі:

1. Методом співосадження синтезувати зразки чистих феритів та їх композитів 3 активним вугіллям.

2. Розрахувати значення граничної і питомої адсорбції та провести критичний аналіз адсорбційної активності синтезованих та досліджуваних зразків.

3. Вивчити кінетику процесів адсорбційного вилучення барвників катіонного та аніонного типів синтезованими зразками.

\section{4. Матеріали та методи}

Усі хімічні речовини, що застосовували в роботі: нітрат нікелю $\left(\mathrm{Ni}\left(\mathrm{NO}_{3}\right)_{2}\right)$, нітрат заліза (III) $\left(\mathrm{Fe}\left(\mathrm{NO}_{3}\right)_{3}\right)$, цитратна кислота $\left((\mathrm{HOOCCH})_{2} \mathrm{C}(\mathrm{OH}) \mathrm{COOH}\right)$ та гідроксид амонію $\left(\mathrm{NH}_{4} \mathrm{OH} 25 \%\right)$ мали аналітичну якість та використовувались без подальшого очищення.

\section{1 Синтез сорбентів}

Синтез чистого нікелевого фериту $\mathrm{F}$ проводили методом співосадження нітратів нікелю (II) та заліза (III) 3 молярним співвідношенням $\left[\mathrm{Ni}^{2+}\right] /\left[\mathrm{Fe}^{3+}\right]=1 / 2$, які повністю розчиняли в дистильованій воді і додавали його у розчин цитратної кислоти із розрахунковим співвідношенням катіонів Ме/цитратна кислота $=1 / 1$. Потім до отриманого розчину додавали розчин гідроксидамонію (концентрації 25 \% мас) для отримання pH 7 (розчин А). Суміш повільно упарювали при постійному перемішуванні за температури $80{ }^{\circ} \mathrm{C}$ до утворення гелю. Отриманий гель висушували за температури $230{ }^{\circ} \mathrm{C}$ протягом 3 годин до утворення ксерогелю, який потім прожарювали за температури $400{ }^{\circ} \mathrm{C}$ упродовж 2 годин у повітряному середовищі.

Синтез чистого нікелевого фериту $\mathrm{F}^{\prime}$ проводили методом співосадження з горінням [11]. Для цього розчин А повільно упарювали при постійному перемішуванні за температури $80{ }^{\circ} \mathrm{C}$ до утворення гелю і продовжували цей процес до утворення ксерогелю. Отриманий ксерогель висушували за температури $230{ }^{\circ} \mathrm{C}$ протягом 3 годин, а потім прожарювали при $400{ }^{\circ} \mathrm{C}$ упродовж 2 годин у повітряному середовищі (рис. 1).

Синтез композитного нікелевого фериту С проводили методом співосадження 3 горінням. До розчину А додавали активоване вугілля марки Norit, у співвідношенні 6/4 (розчин А/активоване вугілля) та повільно упарювали при постійному перемішуванні за температури $80{ }^{\circ} \mathrm{C}$ до утворення гелю і продовжували цей процес до утворення ксерогелю. Отриманий ксерогель прожарювали при $400{ }^{\circ} \mathrm{C}$ протягом 2 годин у повітряному середовищі.

Синтез композитного нікелевого фериту $\mathrm{C}^{\prime}$ проводили методом співосадження з горінням.

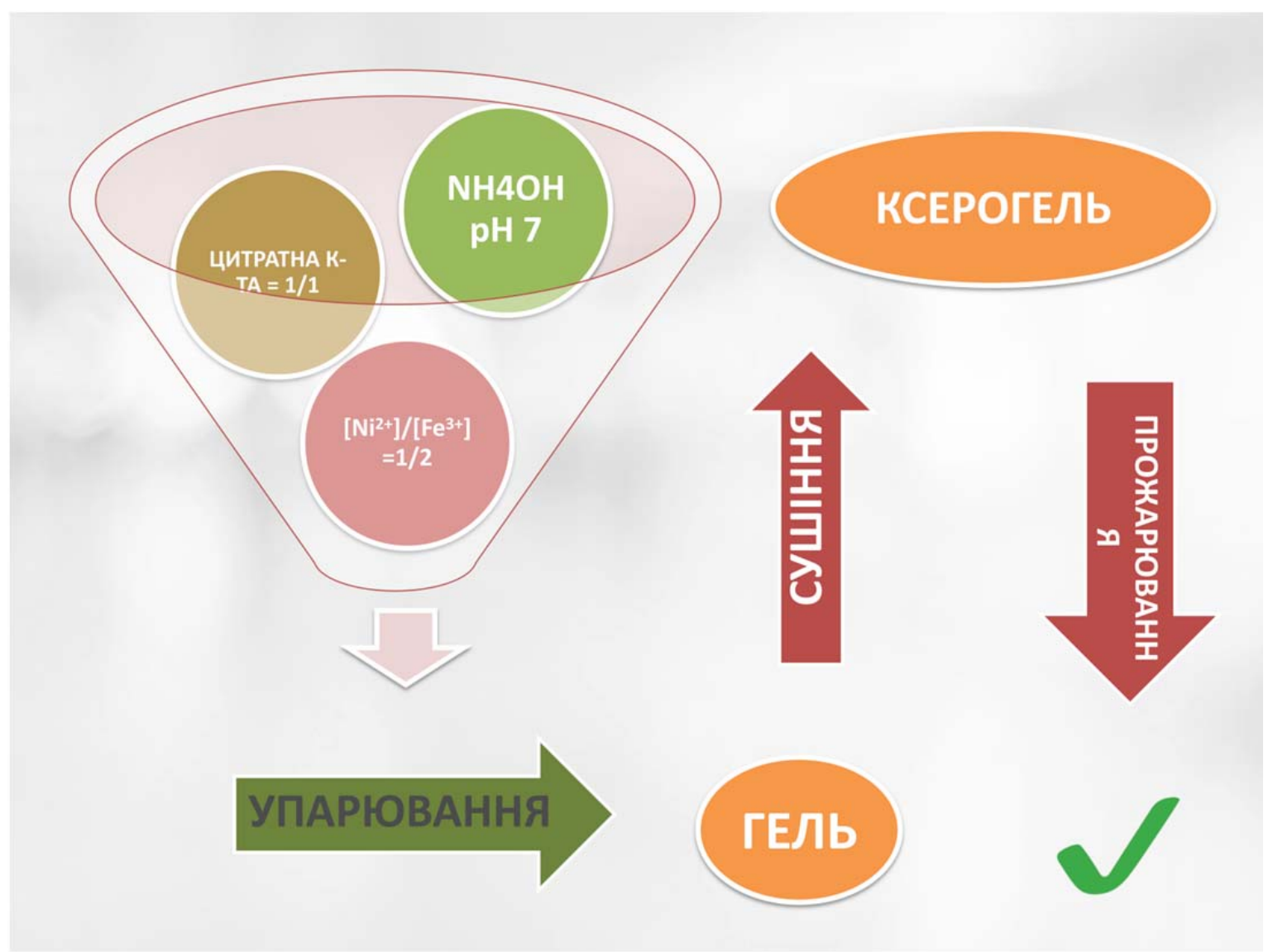

Рис. 1. Схема синтезу феритів F та F' 


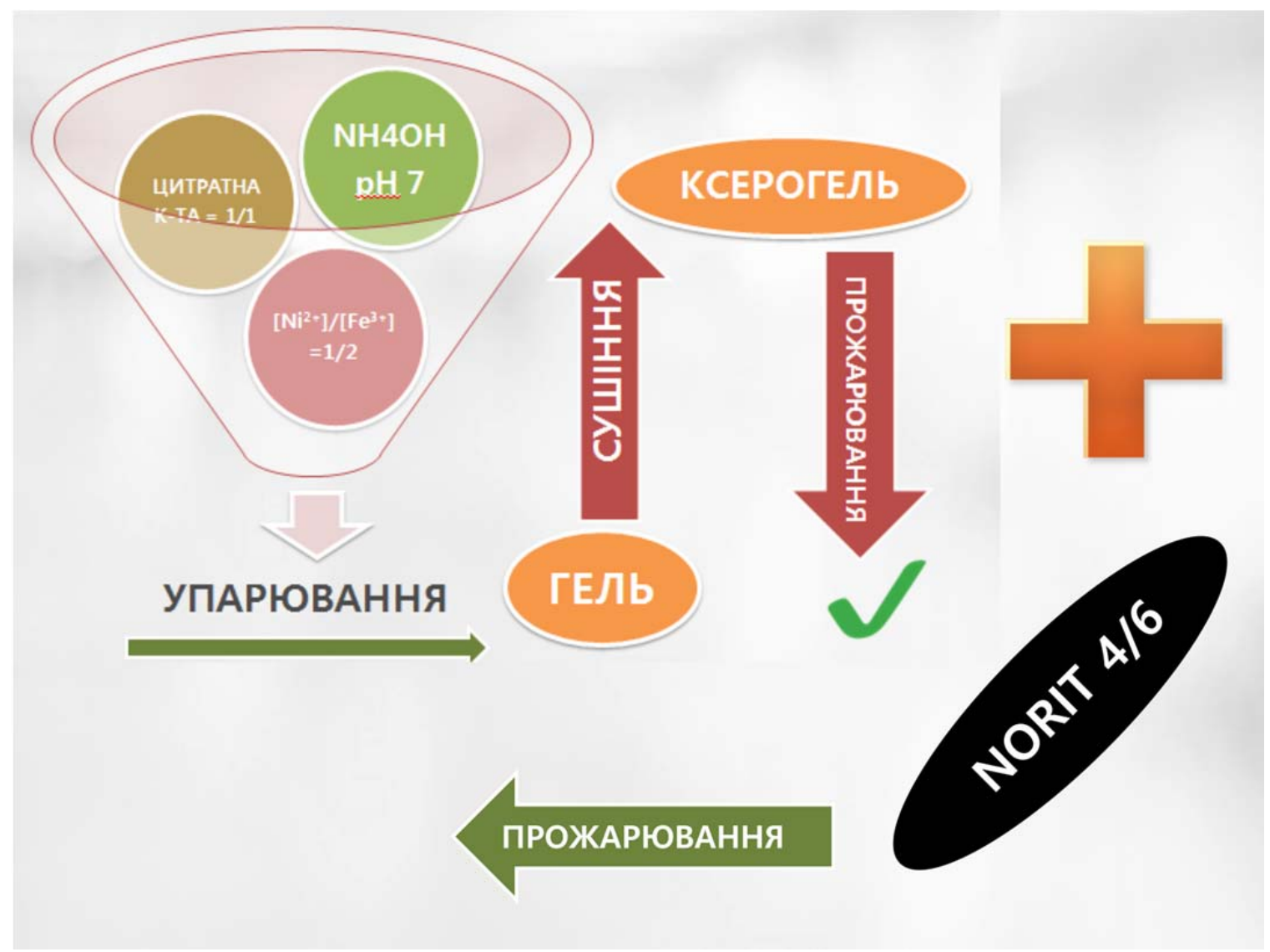

Рис. 2. Схема синтезу композитних феритів $\mathrm{C}_{\text {та }} \mathrm{C}^{\prime}$

Розчин А повільно упарювали при постійному перемішуванні за температури $80{ }^{\circ} \mathrm{C}$ до утворення гелю i продовжували цей процес до утворення ксерогелю. I тільки після цього до отриманого ксерогелю додавали активоване вугілля марки Norit, у співвідношенні 6/4 (розчин А/активоване вугілля) та прожарювали при 400 ${ }^{\circ} \mathrm{C}$ протягом 2 годин у повітряному середовищі (рис. 2).

5. Результати дослідження та їх обговорення 5.1 Визначення адсорбційної ємності досліджуваних сорбентів відносно барвників

Адсорбційну активність синтезованих сорбентів вивчали за адсорбцією барвників метилового синього та конго червоного з модельних водних розчинів трьох різних вихідних концентрацій: $C_{0}=5,10$ та 20 мг/дм ${ }^{3}$, об'єм $\left(V, \mathrm{~cm}^{3}\right)$ яких складав $25 \mathrm{~cm}^{3}$ в кожному експерименті. Maca $(m, \Gamma)$ адсорбенту в кожному досліді становила 0,1 г. Відділення сорбенту від розчину проводили центрифугуванням 3 наступною магнітною сепарацією, після чого встановлювали залишкову концентрацію барвника $\left(C_{3}, \mathrm{мг} /\right.$ дм $\left.^{3}\right)$ фотоколориметричним методом. Адсорбційну ємність $(\Gamma, \mathrm{Mг} / \Gamma)$ розраховували за формулою:

$$
\Gamma=\frac{\left(C_{0}-C_{3}\right) \cdot V}{m} .
$$

Результати цього дослідження представлені на рис. 3, на якому видно, що адсорбційна ємність чистих нікелевих феритів по відношенню до метиленового синього $є$ досить низькою. Але для композитних нікелевих феритів показник адсорбційної ємності $€$ значно вищим, особливо для зразка $\mathrm{C}^{\prime}$. Це пояснюється більш розвиненою питомою площею поверхні композитного фериту, до складу якого входить активне вугілля.

3 рис. 4 видно, що адсорбційна ємність чистих нікелевих феритів по відношенню до конго червоного вища, ніж в попередньому випадку. Це пояснюється наявністю фенольних функціональних груп на поверхні фериту, які являють собою катіонообмінні центри, що сприяють приєднанню катіона барвника за іонообмінним механізмом.

Для композитного нікелевого фериту C' показник адсорбційної ємності також сягає високого значення, але це відбувається завдяки розвиненій питомій площі поверхні композитного фериту, до складу якого входить активоване вугілля. Адсорбційна ємність зразку композитного нікелевого фериту С по відношенню до конго червоного має нульовий показник. 


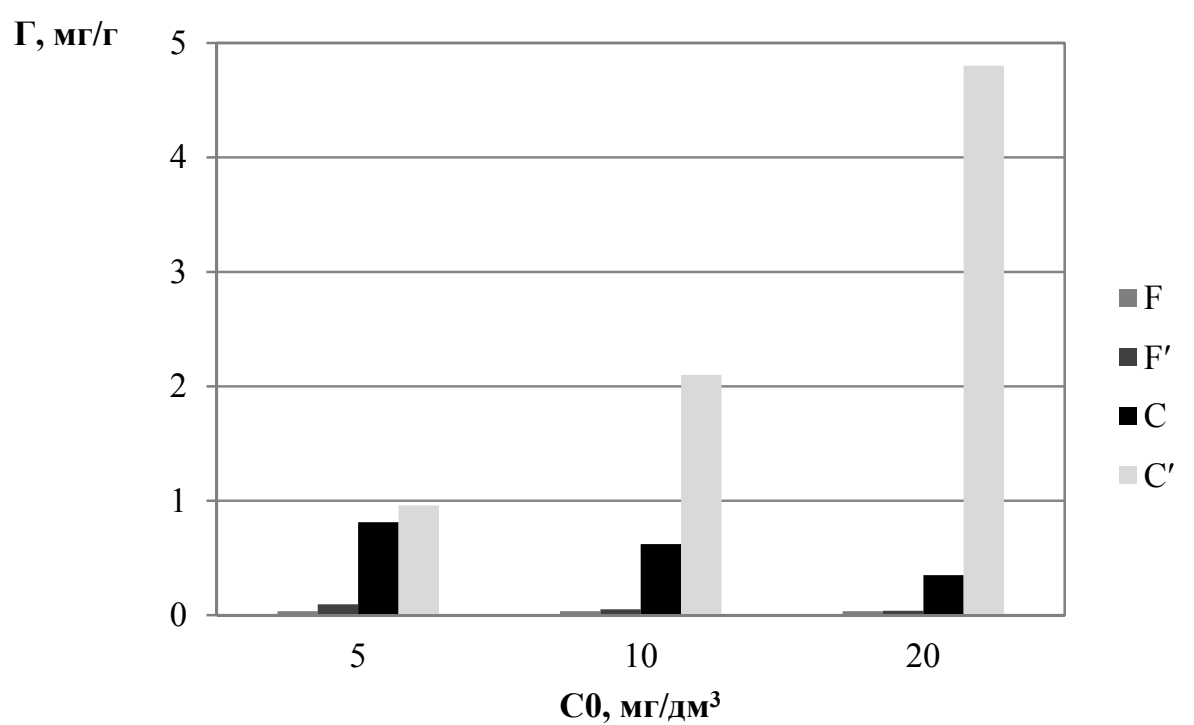

Рис. 3. Адсорбційна ємність досліджуваних сорбентів відносно метилового синього

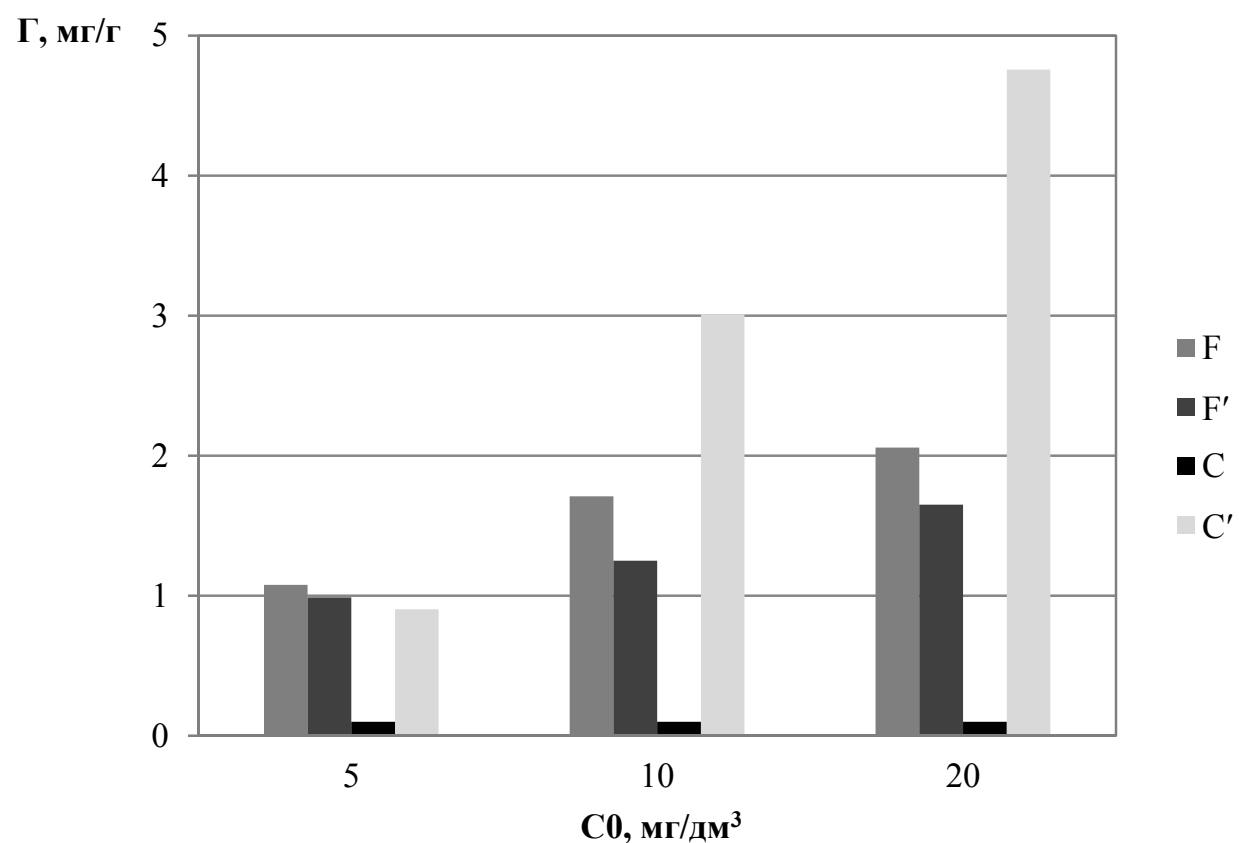

Рис. 4. Адсорбційна ємність досліджуваних сорбентів відносно конго червоного

\section{2 Визначення кінетики адсорбційного ви- лучення барвників \\ Ступінь адсорбційного вилучення метилового} синього та конго червоного досліджували в модельному процесі адсорбції протягом 5, 10, 15, 30, 45, 60, 90 та 120 хвилин 3 водних розчинів початкової концентрації $C_{0}=5$ мг/дм ${ }^{3}$, об'єм яких складав $25 \mathrm{~cm}^{3}(\mathrm{~V}$, $\left.\mathrm{cm}^{3}\right)$ в кожному експерименті. Маса адсорбенту $(m, \Gamma)$ в кожному досліді становила 0,1 г. Ступінь адсорбції $(a, \%)$ розраховували за відповідною формулою:

$$
a=\left(\frac{C_{0}-C_{3}}{C_{0}}\right) \cdot 100 .
$$

Як показано на рис. 5, адсорбційна ємність обох досліджених феритів, по відношенню до метилового синього, практично відсутня і ніяк не зростає зі збільшенням тривалості контакту. По відношенню до конго червоного обидва ферити проявляють високу адсорбційну здатність, яка збільшується від 43 до 84 \% для F та від 38 до 80 \% при збільшенні контакту від 5 до 120 хвилин. Таким чином, адсорбційна здатність чистих феритів по відношенню до аніонного барвника є значно вищою і суттєво залежить від тривалості процесу адсорбції. 


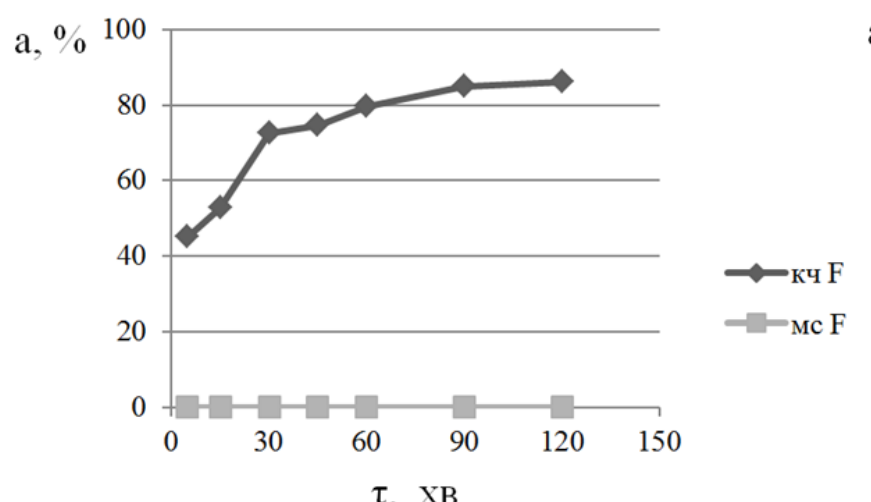

$\tau, \mathrm{XB}$

$a$

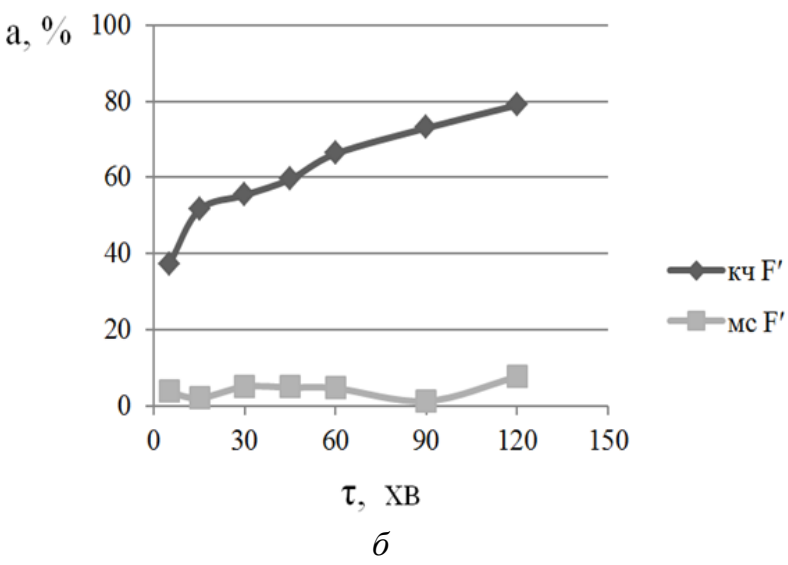

Рис. 5. Кінетика адсорбційного вилучення метилового синього та конго червоного чистими феритами:

$$
a-\mathrm{F} ; \sigma-\mathrm{F}^{\prime}
$$

У випадку композитного фериту С, ситуація виглядає дещо інакше: конго червоний не адсорбується взагалі, але гарно адсорбується метиловий синій. Однак, його адсорбція майже не залежить від тривалості контакту, як це видно на рис. 6. Компози- тний ферит $\mathrm{C}^{\prime}$ має дещо відмінні адсорбційні властивості. Метиловий синій сорбується майже повністю, незалежно від тривалості адсорбції, а конго червоний адсорбується, в середньому, на 75 \%, незалежно від часу.

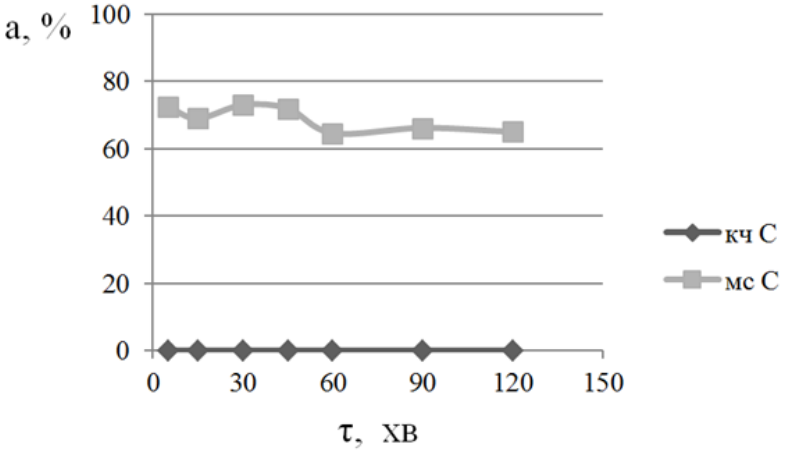

$a$

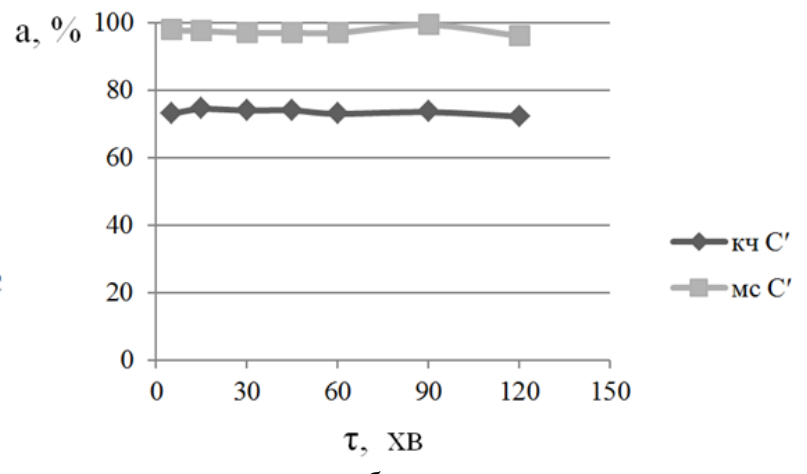

$\sigma$

Рис. 6. Кінетика адсорбційного вилучення метилового синього та конго червоного композитними феритами:

$$
a-\mathrm{C} ; \sigma-\mathrm{C}^{\prime}
$$

Представлені експериментальні результати яскраво ілюструють високу адсорбційну ємність чистих феритів по відношенню до барвника аніонної природи і не виявляють ніякої спорідненості до катіонного барвника метилового синього.

Більш перспективним адсорбційним матеріалом $є$ композитні ферити, причому композит синтезований за другою методикою - співосадження 3 горінням, $є$ більш ефективним: він майже повністю видаляє метиловий синій та на 75 \% конго червоний.

\section{6. Висновки}

1. За допомогою методу співосадження синтезували чотири види сорбенту: два зразки чистих ні- келевих феритів та два зразки їх композитів 3 активним вугіллям.

2. Розрахували значення граничної адсорбції за трьох різних вихідних концентрацій, які продемонстрували високу адсорбційну ємність композитного фериту $\mathrm{C}^{\prime}$ по відношенню до обох барвників.

3. Вивчили кінетику процесів адсорбційного вилучення барвників катіонного та аніонного типів синтезованими зразками.

Результати дослідження показали, що барвник аніонної природи - конго червоний, краще видаляється чистими феритами $\mathrm{F}$ та $\mathrm{F}^{\prime}$, а барвник катіонної природи - композитними феритами $\mathrm{C}$ та $\mathrm{C}^{\prime}$.

\section{Література}

1. Vakili, M., Rafatullah, M., Salamatinia, B., Abdullah, A. Z., Ibrahim, M. H., Tan, K. B. et. al. (2014). Application of chitosan and its derivatives as adsorbents for dye removal from water and wastewater: A review. Carbohydrate Polymers, 113, 115130. doi: http://doi.org/10.1016/j.carbpol.2014.07.007

2. Vaiano, V., Iervolino, G., Sannino, D., Murcia, J. J., Hidalgo, M. C., Ciambelli, P., Navío, J. A. (2016). Photocatalytic removal of patent blue V dye on Au-TiO 2 and Pt-TiO 2 catalysts. Applied Catalysis B: Environmental, 188, 134-146. doi: http://doi.org/10.1016/j.apcatb.2016.02.001 
3. Li, H., Liu, S., Zhao, J., Feng, N. (2016). Removal of reactive dyes from wastewater assisted with kaolin clay by magnesium hydroxide coagulation process. Colloids and Surfaces A: Physicochemical and Engineering Aspects, 494, 222-227. doi: http://doi.org/10.1016/j.colsurfa.2016.01.048

4. Yahiaoui, I., Aissani-Benissad, F., Fourcade, F., Amrane, A. (2015). Enhancement of the biodegradability of a mixture of dyes (methylene blue and basic yellow 28) using the electrochemical process on a glassy carbon electrode. Desalination and Water Treatment, 57 (26), 12316-12323. doi: http://doi.org/10.1080/19443994.2015.1046944

5. Venkatesh, S., Quaff, A. R., Pandey, N. D., Venkatesh, K. (2014). Decolorization and mineralization of C.I. direct red 28 azo dye by ozonation. Desalination and Water Treatment, 57 (9), 4135-4145. doi: http://doi.org/10.1080/19443994.2014.992047

6. Guo, J., Zhang, Q., Cai, Z., Zhao, K. (2016). Preparation and dye filtration property of electrospun polyhydroxybutyratecalcium alginate/carbon nanotubes composite nanofibrous filtration membrane. Separation and Purification Technology, 161, 69-79. doi: http://doi.org/10.1016/j.seppur.2016.01.036

7. Zou, H., Ma, W., Wang, Y. (2015). A novel process of dye wastewater treatment by linking advanced chemical oxidation with biological oxidation. Archives of Environmental Protection, 41 (4), 33-39. doi: http://doi.org/10.1515/aep-2015-0037

8. Makarchuk, O. V., Dontsova, T. A., Astrelin, I. M. (2016). Magnetic Nanocomposites as Efficient Sorption Materials for Removing Dyes from Aqueous Solutions. Nanoscale Research Letters, 11 (1). doi: http://doi.org/10.1186/s11671-016-1364-2

9. Бушкова, В. С., Яремий, И. П., Лисовский, Р. П., Карпик, Б. В. (2017). Структура и сорбционные характеристики порошков ферритов NiCrxFe2 - хO4. Журнал нано- и електронной физики, 9 (2). doi: http://doi.org/10.21272/jnep.9(2).02011

10. Куцан, Н. В., Іваненко, І. М. (2019). Адсорбційні властивості феритів. Вода в харчовій промисловості. Одеса, 59.

11. Лесік, С. М., Возняк, В. С., Іваненко, І. М., Астрелін, I. М. (2019). Пат. № 136147 UА. Спосіб одержання магнітних нікелевих феритів співосадженням з горінням. МПК: (2019.01) C01G 53/00. № u 201900935; заявл.: 30.01.2019; опубл.: 12.08.2019, Бюл. № 15, 4 .

Received date 28.08.2019

Accepted date 12.09.2019

Published date 31.10.2019

Куцан Наталія Володимирівна, кафедра технології неорганічних речовин, водоочищення та загальної хімічної технології, Національний технічний університет України «Київський політехнічний інститут ім. Ігоря Сікорського», пр. Перемоги, 37, м. Київ, Україна, 03056

E-mail: kutsanatasha@gmail.com

Возняк Владислав Степанович, кафедра технології неорганічних речовин, водоочищення та загальної хімічної технології, Національний технічний університет України «Київський політехнічний інститут ім. Ігоря Сікорського», пр. Перемоги, 37, м. Київ, Україна, 03056

E-mail: vlad-woznyak@ukr.net

Іваненко Ірина Миколаївна, кандидат хімічних наук, доцент, кафедра технології неорганічних речовин, водоочищення та загальної хімічної технології, Національний технічний університет України «Київський політехнічний інститут ім. Ігоря Сікорського», пр. Перемоги, 37, м. Київ, Україна, 03056

E-mail: IrinaIvanenko@hotmail.com 